\title{
Experience in improving the mechanism for financing export capacity building programs in south Africa
}

\author{
Miraziz Makhmudov, \\ Researcher of Tashkent State University of Economics
}

http://dx.doi.org/10.26739/2573-5616-2017-7-7-6

Annotation: The article reveals the issues of the experience of improving the mechanism for financing export capacity building programs in South Africa, the dynamics of GDP growth in PPP in South Africa, billions of US dollars, the main trading partners of South Africa, the main export commodity items of South Africa, and the list of priority export support programs in South Africa.

Keywords: improvement, programs, financing, experience, trend, export, partners.

Tnteresting experience of increasing the export potential of the national 1 economy has been accumulated in recent years in the Republic of South Africa, which is the largest state in Africa. mineral.

Occupying the 25th place in the world in terms of territory and population, this country has unique reserves of natural resources that are in high demand on the world market [1]

$-90 \%$ of the world's reserves of platinum group metals,

$-80 \%$ manganese,

$-73 \%$ chromium,

$-45 \%$ vanadium,

$-41 \%$ of gold and

-to $20 \%$ of diamonds. 
Thanks to effective support from the state in matters of financial support for capacity building programs for exporting enterprises, in recent years, the Republic of South Africa has:

-The first place in the world for the extraction of platinum,

-The second place in the world for the production of palladium,

-the third place in the world for the production of gold,

-the sixth place in the world for coal mining and

the ninth place in the world for the production of wool.

Effective measures of support from the state of the subjects of the agrarian sector of the economy provided South Africa with a place of honor in the top twenty countries in terms of agricultural output.

The transition to an intensive build-up of export capacity in the Republic of South Africa was launched much later than other BRICS countries.In the mid-1970s, the new leadership of this country, sharply condemning the policy of the retired Minority Government, accelerated the neoliberal reforms against the backdrop of the country's return to world markets.

The peculiarity of economic reforms in this country was that there is a significant degree of combination of state ownership in the basic branches of the national economy with active export activity of private sector enterprises, which created the creation of a number of new transnational corporations. The real accelerators of the export potential of the enterprises of this country were immigrants from the African majority who received political rights and set off on the second "long road" to economic freedom.

Extremely monopolistic capitalism of the period 1960-1990. today gave way to a more diverse structure of ownership of shares that are in the hands of foreign portfolio managers, as well as state pension and investment funds. Many of the leading exporting companies of South Africa regularly conduct IPO and PSO programs in large foreign stock markets, as well as partici pate in corporate control transactions, receiving up to half of their revenues in the global financial market.

As can be seen from Fig. 2.3.13 in the period from 2005 to 2013, GDP in PPP in South Africa increased from 405.8 to 683.1 billion. US, which allowed it to follow the results of 2014, South Africa to take the 28th place among the economies of the world in nominal GDP. At the same time, South Africa ranks 17th in terms of real GDP growth, while Russia ranks 88 th. 


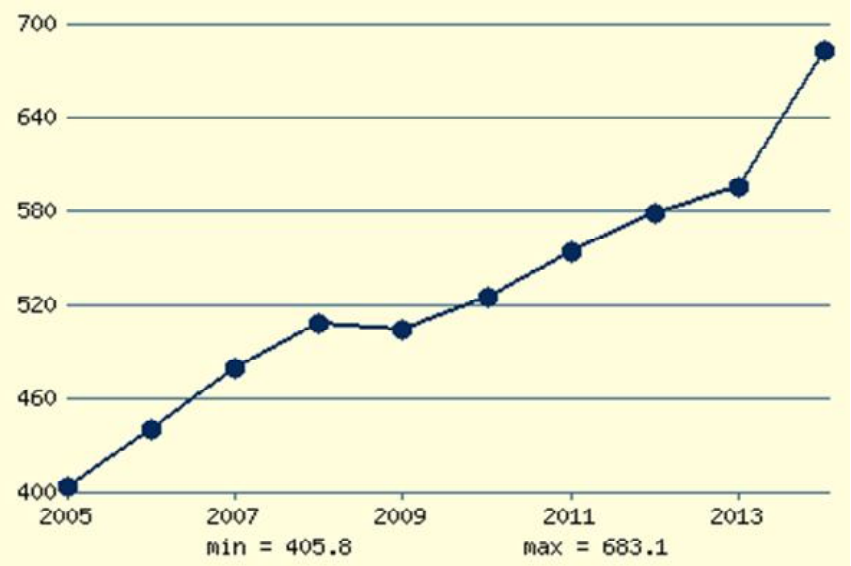

Figure 1. Dynamics of growth in the size of GDP at PPP in South Africa, billion US dollars

The fastest growing industry in 2015 was agriculture, whose growth was $5.6 \%$. Public services took the second place, their growth was $3.0 \%$. In the mining and utilities sectors, there was a decline of $1.6 \%$ and $0.9 \%$, respectively. The sector of industrial production remained almost at the same level, its growth was only $0.3 \%$ [2].

On February 12, 2015, in his address to the nation, President of South Africa J. Zuma stressed that the Government of the country identified 9 strategic priorities for the national economy, designed to increase the export potential of this country (Figure -2)

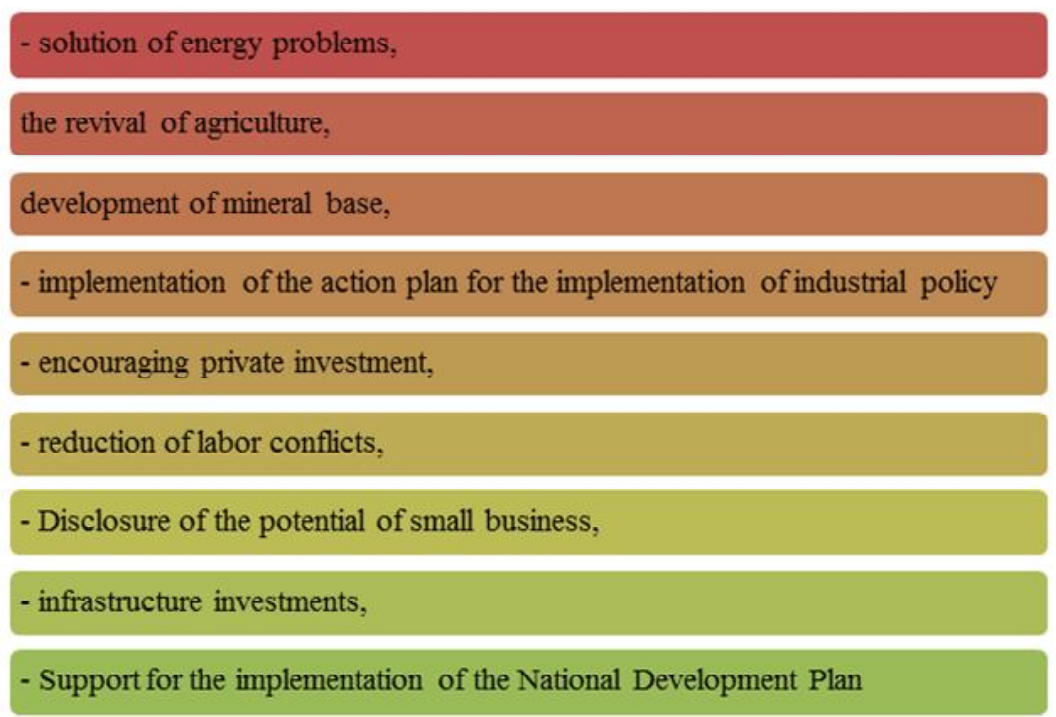

Figure -2.Priority directions of increasing the export potential of South Africa 
On February 25, 2015, in the Budget Report to the Parliament of the country, South Africa's Minister of Finance Nhlanhla Nene noted that South Africa will be able to take advantage of cheaper oil this year, but the main export commodities are adversely affected by the global recession.

Strengthening the export potential of South Africa is facilitated by the deepening of trade and investment ties with African countries, as evidenced by an increase of $19 \%$ in exports to Africa in 2013 and $11 \%$ - in 2014. However, the factors constraining production and investment in the country's economy remain structural problems and issues of competitiveness. As can be seen from figure- 3 for export-oriented sectors of the economy of this country account for no more than 20 percent [3].

Well-coordinated efforts by the state, economic agencies, financial institutions and exporting companies themselves allowed South Africa to increase export potential in a short time, as shown in figure-3.

Currently, South Africa is the most active political player on the African continent, playing a central role in the South African Customs Union, taking a dominant position in the 15-member South African Development Community, and supporting the formation of the New Partnership for Africa's Development and the transformation of the weakening Organization of African Unity in the African Union.[4]

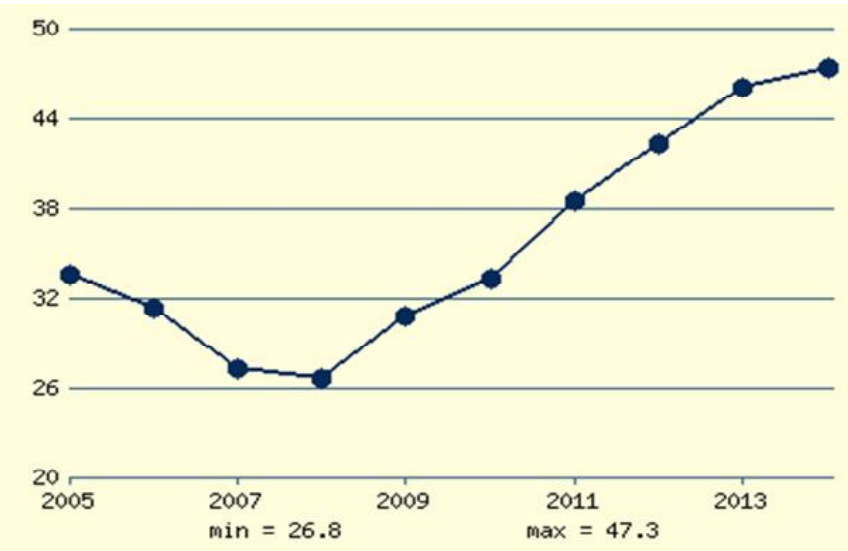

Figure -3. Growth in the volume of exports of companies in South Africa, billion US dollars

As you can see from figure-3, among the main consumers of the products of exporting companies of South Africa in recent years are the leading countries of the world, including China, USA, Japan, Germany, England, India, which indicates the high quality of their products or services.[5] 
Of the five BRICS countries, South Africa has the most continuous experience of dominating the norms of the "free market" and the rule of law, which is important for building up the export potential of these countries and making them a worthy place in the international division of labor. [6] Of particular interest is the assessment of the export potential of the BRICS countries in the World Economic Forum (WEF) Global Competitiveness Report [WEF, 2014], which is based on a combination of quantitative and subjective indicators collected through a survey of business representatives. When considering the parameter "Institutions", this report assigns South Africa 41st place, while Russia is at 121st position. South Africa retains its leading position on such an important indicator as the level of development of the financial market, ranking third in the world. The Gini coefficient of South Africa, equal to 63.1, is one of the highest in the world.

The export capacity of this country was promoted by the program of financial support to export companies operating in the priority sectors of the national economy, developed by the Government of the Republic of South Africa. [7]

At the same time, targeted financial support is provided both to purely South African companies and to companies with foreign participation working in various sectors of industry and services.

\section{References:}

1.www.wikipedia.ru

2. www.ved.gov.ru

3. www.ereport.ru

4. World Economy: Textbook. manual for universities / Ed. Prof. I.P. Mykolaeva. - M .: UNITY_DANA,

5. World economy: introduction to foreign economic activity: A manual for universities / M, B, Elova, E.K. Muraveva, S, M, Panferov, and others; Ed. A, K, Shurkalina, N, S, Tsypina. - M.: The Logos, 2006.

6. Database of Department of Trade and Industry of RSA

7. International economic relations: A textbook for high schools. / E.F. Zhukov, T.I, Kapaevaand others under the editorship of prof.E.F.Zhukov.- M .: UNITY_DANA, 2009. 